\title{
The Road Not Taken - the CJEU Sheds Light on the Role of Fundamental Rights in the European Copyright Framework - a Case Note on the Pelham, Spiegel Online and Funke Medien Decisions
}

\author{
Thom Snijders $\cdot$ Stijn van Deursen
}

Published online: 25 October 2019

(C) The Author(s) 2019

\begin{abstract}
On 29 July 2019, the Court of Justice of the European Union delivered its judgments in three eagerly awaited cases, Pelham, Spiegel Online and Funke Medien, which all relate to the relationship between copyright and (other) fundamental rights. Specifically, an issue arising in these cases is whether the EU copyright acquis allows for fundamental rights to be invoked as an autonomous ground for limiting a copyright, outside of the mechanisms incorporated in the Copyright Directive for that purpose. In its judgments, the Court rejects this possibility and instead locates the role for fundamental rights in the interpretation and implementation of the exceptions and limitations of the Directive. We argue that - while this may render satisfactory results in the great majority of cases in exceptional cases the CJEU's approach towards balancing copyrights and fundamental rights could be at odds with the approach of the European Court of Human Rights, which might reduce the legal certainty sought after by the CJEU. Lastly, we consider the implications of that potential tension for the judicial authorities and other actors within the domestic legal orders of the EU Member States.
\end{abstract}

Keywords EU $\cdot$ Fundamental rights $\cdot$ CJEU $\cdot$ ECtHR $\cdot$ Legal certainty $\cdot$ Balancing

The authors would like to thank Stefan Kulk and Paul Geerts for their useful comments on earlier versions of this article.

T. Snijders $(\varangle) \cdot$ S. van Deursen

Utrecht University, Utrecht, The Netherlands

e-mail: t.snijders@uu.nl 


\section{Introduction}

On 29 July 2019, the Court of Justice of the European Union (CJEU) delivered its judgments in three eagerly awaited cases, Pelham (C-467/17), Spiegel Online (C516/17) and Funke Medien (C-469/17). ${ }^{1}$ These judgments can be seen as forming somewhat of a trinity, in the sense that they all relate to the relationship between copyright and (other) fundamental rights, such as the rights to freedom of expression, freedom of information and freedom of the press. A question underlying all these cases is whether the EU copyright framework is fit to accommodate the tension between these often competing rights in an adequate way. Specifically, a central issue arising in the three cases is whether fundamental rights can serve as autonomous grounds for limiting a copyright, apart from the mechanisms that have been formally incorporated in Directive 2001/29/EC (hereinafter the "Copyright Directive") for that purpose. ${ }^{2}$

This theme, which is central to these cases, merits a combined case note ${ }^{3}$ in which we sketch an image of the CJEU's present stance on the tension between copyright and fundamental rights as well as on the underlying balancing act between legal certainty, flexibility and fairness. Additionally, we analyse the development in the CJEU's case law in light of that in the case law of the European Court of Human Rights (ECtHR). ${ }^{4}$ In connection to that, we discuss the implications for national copyright practices. However, before proceeding to discuss the judgments by the CJEU, a general discussion of the central characteristics of the EU copyright framework, and especially the way fundamental rights considerations have been integrated within this system, is necessary.

\section{The Integration of Fundamental Rights in the Copyright Directive}

The protection of intellectual property is considered a fundamental right, which is among others laid down in Art. 17(2) Charter of Fundamental Rights (CFR) of the European Union and in the first protocol to the ECHR. This right is inter alia further operationalised in the Copyright Directive, which specifically grants authors, performers or producers an exclusive right to exploit their works. ${ }^{5}$ By providing for

\footnotetext{
${ }^{1}$ For the headnotes to these decisions, see this issue of IIC at Pelham and Others https://doi.org/10.1007/ s40319-019-00876-z, Spiegel Online https://doi.org/10.1007/s40319-019-00877-y, and Funke Medien NRW https://doi.org/10.1007/s40319-019-00875-0.

2 Although the referring court in Pelham does not explicitly mention fundamental rights in its questions, but only the possibility of invoking exceptions not mentioned in the Directive, the CJEU nevertheless explicitly applies the same approach to both issues.

3 See on the similarities between the issues being raised in the cases for example also, the opinions of Advocate General Szpunar to the cases of Spiegel Online (paras. 25 and 61) and Funke Medien (para. 28).

${ }^{4}$ In that sense, this contribution can be understood as a follow up to a previous article of ours in this journal. See Van Deursen and Snijders (2018).

5 Arts. 2-4 Copyright Directive.
} 
these exclusive rights, which can be enforced by copyright holders, ${ }^{6}$ copyright can stimulate investment in creativity and innovation and can thereby serve as an impetus for creating works. ${ }^{7}$ Works protected by exclusive rights may, however, also contain information, ideas and other types of material, the free circulation of which the fundamental right to the freedom of information aims to ensure. ${ }^{8}$ The resulting tension between these rights and interests is accommodated in the European copyright acquis at three levels relating to the matter that is touched by the fundamental rights analysis: (1) the subject matter of copyright protection and resulting exclusive rights; (2) the exclusive rights of a copyright holder and the limitations and exceptions to these rights; and (3) the enforcement of these rights. ${ }^{9}$

First of all, the Copyright Directive only protects works, ${ }^{10}$ i.e. subject matter that is original in the sense that it qualifies as the author's own intellectual creation. ${ }^{11}$ To be qualified as such, subject matter has to reflect the personality of the author by displaying the author's creative abilities and his or her free and creative choices. ${ }^{12}$ In written subject matter, an author can do so "through the choice, sequence and combination of [...] words [so] that the author may express his creativity in an original manner". ${ }^{13}$ By requiring originality and by not protecting ideas as such, but rather the specific way in which they are expressed, the Directive provides judges with discretionary space for determining the protective scope of the copyright holder's exclusive rights. In this way, the Copyright Directive pays heed to potentially conflicting rights and interests. ${ }^{14}$ However, if subject matter can be qualified as a work, the Copyright Directive lays down that EU Member States shall provide the creator of that work with the exclusive rights to reproduction (Art. 2), communication (Art. 3) and distribution (Art. 4).

Secondly, fundamental rights also play a role in determining the scope of these exclusive rights of the copyright holder. It follows, for example, from the case law of the CJEU that the right of communication to the public has to be interpreted in such a way to safeguard a fair balance between the rights of the copyright holder, fundamental rights and the public interest. ${ }^{15}$ At the same time the exclusive rights are not absolute, but can rather be limited by the provisions of Art. 5 Copyright Directive, stipulating that Member States may provide for exceptions and limitations to these

\footnotetext{
6 See in that regard also the Directive 2004/48/EC of the European Parliament and of the Council of 29 April 2004 on the enforcement of intellectual property rights.

7 Recital 4 and 10 Copyright Directive.

8 See for example Art. 11 Charter of Fundamental Rights of the European Union (CFR), and Art. 10 European Convention on Human Rights. On this topic also Oliver and Stothers (2017), pp. 521-545.

9 See for an elaborate analysis of the developments in the case law of the CJEU on this matter also Sganga (2019); Oliver and Stothers (2017), pp. 548-563.

${ }^{10}$ See on the scope of the Copyright Directive also Case C-310/17 Levola Hengelo [2018], para. 34.

11 Case C-145/10 Painer C-145/10 [2011] paras. 87-89.

12 Case C-5/08 Infopaq International A/S v. Danske Dagblades Forening [2009], para. 37 and Case C-145/10 Painer C-145/10 [2011] paras. 87-89.

13 Case C-5/08 Infopaq International A/S v. Danske Dagblades Forening [2009], para. 45.

14 See for example Hugenholtz and Senftleben (2011), p. 6.

15 Case C-160/15 GS Media [2016], para. 45. In a similar vein Case C-161/17 Land Nordrhein-Westfalen v. Dirk Renckhoff [2018], para. 41.
} 
exclusive rights. ${ }^{16}$ The system of exceptions and limitations attempts to safeguard a fair balance between the exclusive rights of the author, the rights of others and the general interests of society. ${ }^{17}$ Indeed, for example, in Art. 5(3)(a) one can find a reflection of the freedom of science, ${ }^{18}$ whereas e.g. Art. 5(3)(c) reflects the freedom of information. ${ }^{19}$ According to Recital 32, the Copyright Directive "provides for an exhaustive enumeration of exceptions and limitations to the reproduction right and the right of communication to the public". Such a strict interpretation of the list of exceptions and limitations also follows from the three-step test of Art. 5(5), providing that limitations and exceptions can only apply in special cases that "do not conflict with a normal exploitation of the work [...] and do not unreasonably prejudice the legitimate interests of the right holder." ${ }^{20}$ In its case law, the CJEU has relied upon fundamental rights to interpret the meaning and scope of the Directive - including its exceptions and limitations and their transposition into national law - but has never gone beyond the list as provided by the Directive. It follows from this line of case law that the Court considers exceptions and limitations to be derogations from the general rule that the exclusive rights of the author are protected. Therefore, exceptions and limitations must be implemented and interpreted in a strict sense, while taking account both of their wording, and of their purpose of ensuring a fair balance between the rights and interests involved: "the interpretation of those conditions [in this case for the applicability of the exception for temporary acts of reproduction, $S v D \& T S$ ] must enable the effectiveness of the exception thereby established to be safeguarded and permit observance of the exception's purpose as resulting in particular from recital $31 " .21$

\footnotetext{
16 See Art. 5(2) and (3) for exceptions and limitations to the reproduction right, and Art. 5(3) for exceptions and limitations to the right of communication to the public.

17 Recital 31 Copyright Directive.

18 Art. 5(3)(a) Copyright Directive provides for the use for the purpose of illustration for teaching or scientific research. The freedom of the sciences is laid down in Art. 13 CFR.

19 Art. 5(3)(c) Copyright Directive firstly allows for the reproduction by the press or the making available of published articles on current economic, political or religious topics or of broadcast works or other subject matter of the same character. Secondly, Art. 5(3)(c) Copyright Directive allows for the use of other subject matter in connection with the reporting of current events, to the extent justified by the informatory purpose. Art. 11 CFR lays down the freedom of information.

${ }^{20}$ In literature, it is however argued that the EU's three-step test deviates from the international provisions on which it is based (e.g. Art. 9(2) Berne Convention, Art. 13 TRIPS Agreement, Art. 10 WIPO Copyright Treaty). These original provisions also allow for the scope of the existing exceptions and limitations to be extended as a result of the application of the three-step test. An equally broad interpretation of Art. 5(5) Copyright Directive, in line with these provisions, could therefore be used to relieve the tension between copyright and other fundamental rights and interest, but does not seem to be in line the explicit wording of this provision. See for a further reflection on this debate Geiger and Schönherr (2014), p. 442; Geiger et al. (2014).

21 Case C-403/08 and 429/08 Football Association Premier League [2011], para. 163. A similar approach was followed in Case C-145/10 Eva Maria Painer [2011] in which the Court ruled that the conditions for invoking the the quotation exception of Art. 5(3)(d) Copyright Directive have to interpreted in a strict manner, while at the same time ensuring its effectiveness and while observing its purpose, i.e. to strike a fair balance between the exclusive rights of the author and the rights of others. See paras. 132-137. In Case C-201/13 Deckmyn v. Vandersteen [2014] the Court also explicitly referred to an interpretation of exceptions against their background (paras. 21-24). See further in a similar vein: Case C-314/12 UPC Telekabel Wien [2014], para. 46; C-149/17 Bastei Lübbe [2018], para. 45.
} 
Thirdly, in the Court's case law, fundamental rights in the EU copyright acquis also play a role in copyright enforcement. ${ }^{22}$ In a line of case law relating to enforcement measures aimed at intermediaries that allegedly facilitated the infringement of copyrights, but did not infringe copyright themselves, the Court has made clear that the specific measures that are taken in order to protect the exclusive rights of an author, have to be balanced against (potentially) conflicting fundamental rights. In the words of the CJEU: "national authorities and courts must strike a fair balance between the protection of copyright and the protection of the fundamental rights of individuals who are affected by such measures." 23 On this level, fundamental rights can thus serve as an autonomous ground for limiting specific enforcement measures.

In conclusion, by limiting the role of fundamental rights to an instrument for scrutinising specific enforcement measures aimed at intermediaries and for the interpretation of existing limitations and exceptions, the CJEU has always remained within the boundaries of the closed list of limitations and exceptions. ${ }^{24}$ In its case law it has never allowed for fundamental rights to justify the use of protected works outside the scope of the existing limitations and exceptions. Yet one can question whether that approach is fully satisfactory for dealing with the various conflicts that can arise against the background of copyright, as is exemplified by the three cases that resulted in the German Bundesgerichtshof (Federal Supreme Court) referring questions to the CJEU.

In the following section, we first briefly discuss the relevant facts in each case in order to show how the question of whether fundamental rights or other considerations can justify exceptions or limitations outside of the closed list of Art. 5, crystallised in in these cases. From thereon, we go into the relevant considerations in the CJEU's judgments, which are strikingly similar for all three cases in spite of their markedly different contexts. ${ }^{25}$

\footnotetext{
${ }^{22}$ In the EU, the enforcement of intellectual property rights is covered by Directive 2004/48/EC of the European Parliament and of the Council of 29 April 2004 on the enforcement of intellectual property rights. In Recital 32, this Directive provides: "This Directive respects the fundamental rights and observes the principles recognised in particular by the Charter of Fundamental Rights of the European Union. In particular, this Directive seeks to ensure full respect for intellectual property, in accordance with Article 17(2) of that Charter."

${ }^{23}$ Case C-70/10 Scarlet/SABAM [2011], para. 45. A balance between specific copyright enforcement measures and fundamental rights of others was also at issue in Case C-275/06 Promusicae [2008]; Case C-360/10 SABAM v. Netlog [2012]; C-314/12 UPC Telekabel Wien [2014] and Case C-484/14 McFadden v. Sony Music [2016].

${ }^{24}$ See for further analysis and background of this typology also Van Deursen and Snijders (van Deursen and Snijders 2018), paras 2.3-2.4. See for a further discussion of the Copyright Directive's approach, its focus on exclusive rights and the role of limitations and exceptions: Dreier 2010.

${ }^{25}$ Due to limited space, we only refer to the opinion of Advocate General Szpunar in order to provide further context to the CJEU's considerations. For a more extensive analysis of the opinions of the Advocate General in the three cases, see for example Griffiths (2019); Geiger and Izyumenko (2019).
} 


\section{Invoking Fundamental Rights as External Limitations to Copyright}

\subsection{Pelham}

The case of Pelham concerns the use of a two-second rhythm sequence from the Kraftwerk song "Metall auf Metall" in the song "Nur Mir" composed by Pelham and Haas. Kraftwerk claims among other things that this use infringes their copyright and copyright-related rights. In order to stop the use of this sample and to get compensation for their loss, Kraftwerk initiated legal proceedings in Germany, which eventually resulted in preliminary questions being asked to the CJEU. Aside from raising a number of other important points, the German Federal Supreme Court asked "whether a Member State may, in its national law, lay down an exception or limitation, other than those provided for in Article 5 of Directive 2001/29". ${ }^{26}$ The additional exception, laid down in Art. 24 German Copyright Act (Urheberrechtsgesetz), concerns a "right to free use" which, according to the German court, is not a derogation from, but rather an inherent limitation to the protective scope of copyright. The rationale of that inherent limitation, according to the German Court, is the idea that "it is not possible to conceive of a cultural creation without that creation building upon the previous work of other authors". ${ }^{27}$

\subsection{Spiegel Online}

In the late 1980s, Volker Beck had authored a manuscript on criminal offences relating to sexual offences committed against minors, which had subsequently been published pseudonymously in a book. Confronted over the years with criticism of its content, Beck claimed that the publisher, without his authorisation, edited the manuscript for publication in a way that had distorted his ideas. When the original manuscript of the article was discovered in 2013, Beck - who was by then a member of the German Bundestag - sent the manuscript and the article to newspaper editors in order to prove that the manuscript was indeed altered for publication. However, he did not consent to any publication of the documents; instead he published them on his personal website, with each page containing disclaimers stating that he distanced himself from the ideas contained in the article and stressing that the article had been edited and modified by the publisher of the book. The online news portal Spiegel Online, however, was of the opinion that Beck had misled the public, as they found that whilst the manuscript had been edited before publication, that had not distorted the original meaning. The newspaper then published an online article on this matter, and attached both the manuscript and the original article without the accompanying disclaimers. Volker Beck instigated legal proceedings against Spiegel Online, claiming infringement of his copyright. Spiegel Online for its part invokes the fundamental rights of freedom of information and freedom of the press, which are enshrined in Art. 11 of the Charter, leading the German Court to essentially ask the question whether those fundamental rights can "justify

\footnotetext{
${ }^{26}$ Case C-467/17 Pelham [2019], para. 57.

27 Case C-467/17 Pelham [2019], para. 56.
} 
exceptions or limitations to the exclusive rights of authors enshrined in Art. 3(1) of Directive 2001/29 beyond the existing exceptions and limitations provided for by Art. 5 of the Directive". ${ }^{28}$

\subsection{Funke Medien}

That exact same question is also considered by the Court in the case of Funke Medien. ${ }^{29}$ Media conglomerate Funke Medien exploits the website of the Westdeutsche Algemeine Zeitung (WAZ). It has been involved in a legal dispute with the German State concerning the publication of classified government reports documenting the presence and actions of the German Armed Forces in Afghanistan from 2002 until 2016. ${ }^{30}$ After initially being refused access to these documents, the WAZ somehow managed to obtain them through other means and subsequently published them on its website. In response, the German State has claimed infringement of its exclusive rights to these documents. In a similar vein to Spiegel Online, Funke Medien argues that the fundamental rights to freedom of expression and freedom of information and the right to freedom of the press ought to serve as an external exception to the German State's exclusive rights, as it cannot rely on any of the German implementations of the exceptions or limitations listed in Art. 5.

\subsection{The Approach of the CJEU}

The Court has formulated nearly identical answers to these questions, which are therefore discussed here in combination. According to the Court, the list of Art. 5 is meant to be exhaustive, and it refers to its own earlier case law in which it has often pointed this out. ${ }^{31}$ The Court then reminds us of the fact that the harmonisation effectuated by the Directive aims to safeguard a fair balance between the interests of the holders of copyright and their related intellectual property rights, and the interests and fundamental rights of users, as well as the public interest. ${ }^{32}$ The system of exclusive rights of the author and the limitations and exceptions to those rights, which we discussed in the previous section, are the mechanisms that allow for such a fair balancing according to the Court. ${ }^{33}$

The Court then specifically goes into the matter of fundamental rights, which have been enshrined in the CFR. In addition to what it said in the preceding

\footnotetext{
${ }^{28}$ Case C-516/17 Spiegel Online [2019], para. 40.

29 Compare Case C-469/17 Funke Medien [2019], para. 55 and Case C-516/17 Spiegel Online [2019], para. 40. See also for a more elaborate discussion of the case Van Deursen and Snijders (2018), pp. 1094-1095.

${ }^{30}$ See for a more extensive summary of the facts Case C-469/17 Funke Medien [2019], paras. 9-14.

31 Referring to the Explanatory Memorandum to the Directive as well as Recital 32 see Case C-467/17 Pelham [2019], para. 58; Case C-516/17 Spiegel Online [2019], para. 41; Case C-469/17 Funke Medien [2019], para. 56. We discuss this body of case law at length in Van Deursen and Snijders (2018). See also Sect. 2 of the current contribution.

32 Case C-467/17 Pelham [2019], para. 59; Case C-516/17 Spiegel Online [2019], para. 42; Case C-469/17 Funke Medien [2019], para. 56.

33 Case C-467/17 Pelham [2019], para. 60.
} 
paragraphs, the Court emphasises in both Spiegel Online and Funke Medien that the exceptions and limitations of the Directive are "specifically aimed at favouring fundamental rights such as the freedom of expression [...] [and] the freedom of the press [...] over the interest of the author", albeit through a fair balance that does not unreasonably prejudice the reasonable interests of the right holder or conflict with a normal exploitation of the work; again, this fair balance is enabled through the mechanisms of the Directive. ${ }^{34}$

Consequently, the Court holds that allowing Member States to derogate from the author's exclusive rights beyond the existing limitations and exceptions provided for through the list of Art. 5 would not only conflict with the EU lawmaker's explicit intentions, as evidenced by Recital 32 and the Explanatory Memorandum to the Copyright Directive, but would also endanger both the effectiveness of the harmonisation that the Directive seeks to achieve and its objective of creating legal certainty. ${ }^{35}$ To this, it adds a reference to Recital 31 of the Directive, stating explicitly that former differences in the exceptions and limitations to certain restricted acts had direct negative effects on the functioning of the internal market of copyright and other related rights and that the list of exceptions and limitations set out in Art. 5 "is aimed at ensuring such proper functioning of the internal market". 36

All in all, this means that not only any additional exception or limitation such as the German "right to free use" is out of bounds, but that the fundamental rights provided for in the Charter cannot serve as autonomous justificatory grounds for limitations or exceptions to copyright outside of the existing system. However, the Court also notes that both the transposition into domestic law by the Member States of provisions that do not constitute measures of full harmonisation and the interpretation of those implementations are governed and circumscribed by inter alia the fundamental rights laid down in the Charter. In line with its earlier case law, it explicitly states that the interpretation of exceptions and limitations in light of fundamental rights can be a way to ensure a fair balance between the different rights and interests at stake within the system of the Copyright Directive. In the words of the Court, a national court must "rely on an interpretation of those provisions which, whilst consistent with their wording and safeguarding their effectiveness, fully adheres to the fundamental rights enshrined in the Charter". ${ }^{37}$ Accordingly, fundamental rights are not only operationalised through their substantive role in the mechanisms of the Directive, but also in the way they bind Member States' legislators in their implementation of the exceptions and limitations into domestic laws, and judicial authorities in their interpretation of those provisions.

\footnotetext{
34 Case C-469/17 Funke Medien [2019], para. 60; Case C-516/17 Spiegel Online [2019], para. 45.

35 Case C-516/17 Spiegel Online [2019], para. 47; Case C-467/17 Pelham [2019], para. 63; Case C-469/17 Funke Medien [2019], para. 62.

36 Ibid.

37 Case C-516/17 Spiegel Online [2019], para. 59.
} 


\section{The Current CJEU's Judgments in the Dynamic European Legal Landscape}

In many ways, the Court's considerations outlined above should not strike most spectators as a great surprise. As the Court itself points out, it has stressed time and again that the list of Art. 5 Copyright Directive is indeed closed, and the rulings discussed here do not diverge from that established course. However, it might just be the fact that the Court keeps on going straight ahead that gives rise to various questions. We therefore explore two major and intimately related aspects relevant to these judgments, namely that of their relationship to the case law of the ECtHR, and that of the implications of these judgments for the domestic practices of the EU Member States.

As the CJEU itself points out, the key objectives of the Directive were to harmonise copyright law in the EU and to achieve a high degree of legal certainty therewith. ${ }^{38}$ The fact that the Directive uses a closed list of exceptions and limitations was a direct corollary of that ambition. Whilst the Court rightly points out that fundamental rights considerations were not ignored during the drafting process, one can still legitimately question whether the use of a closed list best allows for the anticipation and resolution of all potential fundamental rights conflicts that can arise within copyright law. Their role as yardsticks for the interpretation and implementation of the existing limitations and exceptions, could strip them of their corrective potential in exceptional and unforeseen cases. ${ }^{39}$ As a result, the fundamental rights of freedom of expression and of the media may appear to play second fiddle in a piece of legislation principally oriented towards ensuring the proper functioning of the internal market.

At this point, it is instructive to consider the advisory opinions to the three cases by Advocate General Maciej Szpunar. In his opinion on Spiegel Online, he started off by underlining the crucial role that the fundamental rights of freedom of expression and the freedom of the media play in a democratic society. ${ }^{40}$ Later on, he noted also that these rights are not absolute and copyright can in many cases override those fundamental rights. ${ }^{41}$ With regard to this balancing act, he pointed out that the weighing of fundamental rights is usually the prerogative of the legislature, with the judiciary intervening only in those exceptional cases in which the essence of a fundamental right is at stake. ${ }^{42}$ This of course begs the question of when the essential content of a fundamental right is actually in danger of being

\footnotetext{
38 Case C-516/17 Spiegel Online [2019], para. 35.

39 In this regard it is interesting to note that the Dutch Supreme Court in 1995 (so before the entering into force of the Copyright Directive) mentioned that the inclusion of a list with explicit exceptions and limitations in Dutch copyright law did not exclude the possibility of making a balancing act between the rights of the copyright holder and the societal or economic interests of others or the general interest. This would especially be the case if the need for the exception or limitation concerned is not acknowledged by the legislator and if this would fit within the system of the law, in light of the developments of copyright as a means of protecting commercial interests. See Dutch Supreme Court 20 October 1995 (Dior/Evora) para. 3.6.2.

40 Opinion of Advocate General Szpunar in C-516/17 Spiegel Online [2019], paras. 1-3.

41 Opinion of Advocate General Szpunar in C-516/17 Spiegel Online [2019], para. 65.

42 Opinion of Advocate General Szpunar in C-516/17 Spiegel Online [2019], para. 62.
} 
infringed, so that judicial intervention is vindicated. In his opinion on Funke Medien, as was recently also pointed out by Geiger and Izyumenko, Szpunar took a less reserved stance, and openly stated that under some circumstances, copyright "must yield to an overriding interest relating to the implementation of a fundamental right or freedom". His opinion thus points towards permitting an external role for fundamental rights in particular cases. ${ }^{43}$ This is of course contrary to the general idea that those rights are sufficiently safeguarded through the Directive's mechanisms. However, as evidenced by its judgments, the CJEU does not want to give into this theoretical possibility and does not hint towards fundamental rights playing any role that exceeds their use as yardsticks for the interpretation of the provisions of Art. 5.

The Advocate General's considerations highlighted here stand in clear relation to the case law of the ECtHR. In particular, its 2013 ruling in the case of Ashby Donald has put pressure on the closed system of Art. 5 of the Directive. ${ }^{44}$ In that case, the ECtHR essentially held that the lawfulness of particular copyright enforcement measures is to be assessed through the lens of Art. 10(2) ECHR. This means that copyright enforcement measures need to be provided for by law, pursue a legitimate aim, and are necessary in a democratic society. It ensues from that approach that the mere fact that a user of a protected work cannot rely on one of the exceptions or limitations of Art. 5 Copyright Directive would not be enough to justify an enforcement measure or sanction, and judicial authorities will need to assess the legitimacy of such measures through the Art. 10(2) ECHR test on a case-by-case basis instead. ${ }^{45}$ Notably, this approach by the ECtHR frames copyright enforcement measures in general as derogations from the freedom of information and freedom of expression; on that view, all copyright enforcement measures must be in accordance with Art. 10 ECHR. As we pointed out earlier, such an external role for fundamental rights has only been accepted by the CJEU in a very limited set of cases concerning enforcement measures specifically directed towards intermediaries who were themselves not the actual users of copyright protected material. ${ }^{46}$ The ECtHR extends that treatment to all enforcement measures, including those that are general and principally directed towards users.

In Ashby Donald, the Court did not go so far as to heavily scrutinise whether the domestic court in that case had actually carried out the balancing test of Art. 10(2) ECHR. ${ }^{47}$ The margin of appreciation allowed to the domestic court followed from the ECtHR's established approach, in which it makes a principled distinction between cases concerning commercial speech on the one hand, and cases concerning political speech or discussions of a general public interest on the

\footnotetext{
43 Opinion of Advocate General Szpunar in C-469/17 Funke Medien [2019], para. 40; Geiger and Izyumenko (2019).

44 Ashby Donald v. France App No. 36769/08 (ECtHR, 10 January 2013).

45 Voorhoof and Høedt-Rasmussen (2013a).

46 Interestingly, the CJEU has not explicitly justified its approach in this regard by referring to any essential differences between intermediaries and actual users that consequently require a different treatment. Nevertheless, this distinction seems to be a principal deciding factor in those cases.

47 According to its established case law, the ECtHR principally leaves it to signatory states to balance conflicting convention rights. See Voorhoof and Høedt-Rasmussen (2013b).
} 
other. ${ }^{48}$ In Ashby Donald, the users had made use of the protected works only for the motive of profit, so that the ECtHR only marginally examined the decision and reasoning of the domestic court. However, had the case concerned political speech or the discussion of a matter of general public interest, the margin of appreciation would have been significantly reduced. In discussing the importance of the distinction, the ECtHR also further specified potential cases that would require a reduced margin of appreciation, such as those that concern the "use of public documents" or those that involve "journalists and media exercising their public watchdog function in a democracy". 49

In light of the distinction between commercial interests, and political speech and matters of general public interest, it is curious that the judgment by the CJEU in Pelham is nearly identical to the judgments in Spiegel Online and especially Funke Medien. Not only do vastly different interests underpin the justification of the additional exception in Pelham, but the case can arguably also be differentiated from the other two in terms of the type of speech that it concerns. Both Spiegel Online and Funke Medien seem potential candidates for a reduced margin of appreciation seen from the point of view of the ECtHR, given their potential importance for societal debate. For the case of Spiegel Online, the Advocate General did not consider this to be the case, but in his opinion in Funke Medien, he explicitly argued that the particular circumstances of the case indeed required an external balancing of fundamental rights. Accordingly, he applied the balancing test of the ECtHR and approached the copyright enforcement measure as a derogation to Funke Medien's rights to freedom of expression and freedom of the press, eventually concluding that the derogation formed by the enforcement measure could not be justified. ${ }^{50}$ Notwithstanding this, the Advocate General, who of course recognised the risk involved in opening up the system of the closed list of Art. 5, duly emphasised the importance of a case-by-case approach, and is open to an external role for fundamental rights only when prompted by the specific circumstances of a particular case. ${ }^{51}$

Returning then to the present judgements of the CJEU, it is important to nuance their implications, as the CJEU has shown itself willing to extend the role and scope of the exceptions and limitations with its requirement of an interpretation in light of a fair balance between copyright and other fundamental rights. With regard to the case of Funke Medien, an interpretation of Art. 5(3)(c) Copyright Directive in light of the criteria set out by the ECtHR in the case of Ashby Donald, might lead to the conclusion that the documents at issue in the Funke Medien case are covered by the second case provided for by Art. 5(3)(c). That provision allows for the use of works or other subject matter in connection with the reporting of current events, to the extent justified by the informatory purpose. As a result of such a broad

\footnotetext{
48 The distinction between types of speech was introduced by the ECtHR in Mouvement Raëlien Suisse v. Switzerland App No. 16354/06 (ECtHR, 13 July 2012), para. 61.

49 Voorhoof and Høedt-Rasmussen (2013a).

50 Opinion of Advocate General Szpunar in Case C-469/17 Funke Medien [2019], paras. 50-66.

51 See for example Opinion of Advocate General Szpunar in Case C-469/17 Funke Medien [2019], paras. 31 and 71.
} 
interpretation, almost all cases in which the press uses copyright-protected material on current events seem to be covered by exceptions; thus, even a case like Funke Medien, in which the Advocate General deemed an external balancing between fundamental rights to be appropriate, can possibly be accommodated within the Directive's mechanisms according to the Court.

Problematic practical situations might, however, still arise in borderline cases, for example, those in which non-published, copyright-protected material not relating to current events is used. Directly invoking a fundamental right could then possibly be the only way to ensure a fair balance between the rights and interests at stake. In this sense, only time can tell whether the role given to fundamental rights by the CJEU will indeed prove sufficient, and the tension between the CJEU's approach and that of the ECtHR is not taken away entirely.

That conclusion gives rise to another major question, namely what the impact of these decisions will be for the practices of courts and legislators in the Member States. The strict approach taken by the CJEU in these cases is mainly driven by the need to preserve legal certainty and thereby to ensure the effectivity of the harmonisation. ${ }^{52}$ Yet, in light of the tension described above, it is doubtful that the present judgments fully succeed in ensuring that legal certainty. This is fueled further by what some see as a more or less ad hoc approach to fair balancing by the Court without a transparent normative framework. ${ }^{53}$ According to Art. 52(3) CFR, in so far as rights laid down in the CFR are also guaranteed by the ECHR, the meaning and scope of these rights shall be the same as that of their counterpart in the ECHR. The protection of intellectual property as well as of the freedom of expression and information are rights that are laid down in both the ECHR and the CFR. According to established case law, EU law has both direct effect in, as well as primacy over domestic law of EU Member States. ${ }^{54}$ At the same time, all EU Member States are bound by the ECHR as signatories to this instrument. ${ }^{55}$ In their respective lines of case law, the CJEU and the ECtHR do, however, seem to apply different standards for operationalising both rights. This can eventually lead to confusing situations for domestic courts, which have to comply with different - and potentially even partially contradicting - standards. ${ }^{56}$ Here, it is important, however, to keep in mind that the European copyright acquis harmonises copyright and its enforcement in all EU Member States. The ECHR at the same time is of a different character, given its often broad margin of discretion. As a result of this, it will only become relevant in case national practices exceed the lines of this margin of discretion.

\footnotetext{
52 Supra, at 35.

53 See e.g. Jongsma (2019); and Peukert (2015).

54 Case 26/62 Van Gend \& Loos [1963]; and Case 6/64 Costa/ENEL [1964]. See for a more extensive discussion of the effects of European law in the national legal systems also Bubek (2014).

55 See also Art. 1 ECHR.

56 This can be problematic in light of the aim of a parallel interpretation of the CFR and the ECHR. See Joint communication from Presidents Costa and Skouris, available at https://www.echr.coe.int/ Documents/UE_Communication_Costa_Skouris_ENG.pdf. On the relationship between the CFR and the ECHR in general, see also Jans et al. (2015), pp. 155-159.
} 
It can be argued that national (procedural) law might offer sufficient opportunities for navigating around these issues and to find a balance between the rights and interests involved on a case-by-case basis. ${ }^{57}$ In light of the CJEU's emphasis on harmonisation and its resulting strict approach, it remains, however, questionable to what extent such "shortcuts" are viable. In Dutch law, for example, users of copyright protected materials could invoke Art. 3:13 of the Dutch Civil Code ("abuse of right") in order to prevent copyright holders from using their exclusive rights if this damages their interests. Abuse of right may occur when a right "is exercised with no other purpose than to damage another person or with another purpose than for which it is granted or when the use of it, given the disparity between the interests which are served by its effectuation and the interests which are damaged as a result thereof, in all reason has to be stopped or postponed". ${ }^{58}$ In our view, however, such an approach - which bears similarities to the way in which fundamental rights were used in the Ashby Donald case - would create a situation in which a copyright holder cannot enforce his rights in practice. According to the CJEU's case law such a de facto limitation of the copyright holder's exclusive rights seems to be contrary to the harmonising efforts of the Copyright Directive and might harm the legal certainty in a way similar to accepting an external limitation or exception.

Lastly, the current approach of the CJEU might also have an impact on the transposition of the Directive into the domestic legal systems of the EU Member States. In the current judgments, the CJEU has made clear that the transposition and implementation of the exceptions and limitations cannot be used to compromise the objectves of the Directive. These are, according to the $\mathrm{CJEU}^{59}$ and Recital 31, inter alia, to ensure a fair balance between rights and interests of right holders and of other users and to respect the fundamental rights as laid down in the CFR. ${ }^{60}$ Thereby, the CFR could have a harmonising effect on the European copyright acquis, as it might be necessary for EU Member States in order to meet these objectives to implement certain exceptions or limitations into their legal order, in spite of their facultative character. ${ }^{61}$

The effect of the discussed cases thereby might be twofold: not only does the Court clarify in what way fundamental rights may be used in relation to the interpretation of exceptions and limitations to the right holder's exclusive rights, but

\footnotetext{
57 See for examples of the ways in which domestic law can be used in order to strike a balance between copyright and other fundamental rights and interests Hugenholtz and Senftleben (2011), pp. 10-12; Sganga and Scalzini (2017).

58 Translation via http://www.dutchcivillaw.com/civilcodebook033.htm. See also for example the German pendant in Art. 226 German Civil Code or the French Art. 32-1 Civil procedural code. French law also provides for specific provisions on abuse of intellectual property rights in Art. 121-3 and 122-9 Code de la propriété intellectuelle.

59 C-469/17 Funke Medien [2019], para. 51.

60 See also Art. 6 Treaty on the Functioning of the European Union.

61 This is also advocated by the Advocate General in his opinion to Case C-467/17 Pelham [2019], para. 77 and to Case C-469/17 Funke Medien [2019], paras. 38-39. See on this potentially harmonising effect of the CFR also Griffiths (2013). With regard to this effect in relation to the judgment of the court in Case C-201/13 Deckmyn v. Vandersteen [2014], Sganga (2019), para. 2.3; Griffiths (2018).
} 
potentially also how they should be used in the implementation and transposition into national law in order to ensure both the Copyright Directive and the Charter's full effect.

\section{Conclusion}

"Two roads diverged in a yellow wood, And sorry I could not travel both". These two lines form the start of Robert Frost's famous poem "The Road Not Taken" and describe the feeling the audience might have when reading the judgments of the CJEU in the cases of Pelham, Funke Medien and Spiegel Online. With the questions of the German Federal Supreme Court in these three cases, the CJEU arrived at the place where two roads diverged: the road of a genuine judicial balancing act between fundamental rights, and the road of full harmonisation of European copyright law.

The CJEU seems to have chosen the latter road, by not allowing fundamental rights to play a role as an external limitation to the exclusive rights of copyright holders beyond the closed list of exceptions and limitations provided for by the Copyright Directive - or at least not as a general possibility. This is in line with the CJEU's earlier case law, in which fundamental rights only played a role in the qualification of subject matter as a work and determining the scope of the resulting exclusive rights (level 1), in the interpretation of existing exceptions and limitations (level 2), and in assessing specific enforcement measures aimed at intermediaries facilitating copyright infringement (level 3). The case law of the EctHR, however, created room for a genuine balance to be made between the enforcement of copyright and fundamental rights - thereby adding the possibility of a de facto limitation of the exclusive rights of the copyright holder. This difference in approach might, however, in exceptional but nevertheless imaginable situations, put national courts yet again at the crossroads, as they have to abide by both the standards of the ECHR and the Copyright Directive. In cases in which the exercise of the copyright holder's exclusive rights conflicts with other fundamental rights, domestic courts therefore have to choose between legal certainty and the flexibility that might be required in order to ensure a fair balance to be made between the rights and interests involved. In light of the CJEU's current line of case law, it remains questionable to what extent there is still discretionary room for national courts to balance those rights on the basis of national (procedural) law; a balancing act that results in a de facto limitation of the copyright holder's exclusive rights might be considered to unacceptably distort the harmonisation efforts of the Copyright Directive. From the current judgments it seems to follow that this room can only exist in cases that are covered by one of the Copyright Directive's provisions.

Finally, although the wording of Art. 5 Copyright Directive suggests that the transposition of exceptions and limitations into domestic law is facultative, the discussed judgments might have the result that some of the exceptions and limitations have to be implemented into national law in order to ensure the fair balance between copyright and other fundamental rights that is required by the CJEU. 
Open Access This article is distributed under the terms of the Creative Commons Attribution 4.0 International License (http://creativecommons.org/licenses/by/4.0/), which permits unrestricted use, distribution, and reproduction in any medium, provided you give appropriate credit to the original author(s) and the source, provide a link to the Creative Commons license, and indicate if changes were made.

\section{References}

Bubek M (2014) The effects of EU law in the national legal systems. In: Barnard C, Peers S (eds) European Union law. Oxford University Press, Oxford

Dreier T (2010) Limitations: the centerpiece of copyright in distress. J Intellect Prop Inf Technol Electron Commerce Law 1:50-54

Geiger C, Izyumenko E (2019) Freedom of expression as an external limitation to Copyright Law in the EU: the Advocate General of the CJEU shows the way. Eur Intellect Prop Rev 3:131-137

Geiger C, Schönherr F (2014) The Information Society Directive. In: Stamatoudi I, Torremans P (eds) EU Copyright Law. Edward Elgar Publishing, Cheltenham

Geiger C, Gervais D, Senftleben M (2014) Understanding the 'three-step test'. In: Gervais D (ed) Research handbook on international intellectual property law. Edward Elgar Publishing, Cheltenham

Griffiths J (2013) Constitutionalising or harmonising? The Court of Justice, the right to property and European Copyright Law. Eur Law Rev 38:65-78

Griffiths J (2018) Taking power tools to the acquis - The Court of Justice, the Charter of Fundamental Rights and European Union Copyright Law. In: Geiger C et al (eds) Intellectual property and the judiciary. Edward Elgar Publishing, Cheltenham

Griffiths J (2019) European Union copyright law and the Charter of Fundamental Rights-Advocate General Szpunar's Opinions in (C-469/17) Funke Medien, (C-476/17) Pelham GmbH and (C-516/ 17) Spiegel Online. ERA Forum 1:35-50

Hugenholtz PB, Senftleben MRF (2011) Fair use in Europe. In search of flexibilities. Amsterdam Law School Legal Studies Research Paper No. 2012-39

Jans JH et al (2015) Europeanisation of public law. Europa Law Publishing, Amsterdam

Jongsma D (2019) AG Szpunar on copyright's relation to fundamental rights: one step forward and two steps back? IPRinfo 1/2019

Oliver P, Stothers C (2017) Intellectual property under the Charter: are the Court's scales properly calibrated? Common Mark Law Rev 2:517-566

Peukert A (2015) The fundamental right to (intellectual) property and the discretion of the legislature. In: Geiger C (ed) Research handbook on human rights and intellectual property. Edward Elgar Publishing, Cheltenham, pp 132-148

Sganga C (2019) A decade of fair balance doctrine, and how to fix it: Copyright versus Fundamental Rights before the CJEU from Promusicae to Funke Medien, Pelham and Spiegel Online. Eur Intellect Prop Rev 11:683-696

Sganga C, Scalzini S (2017) From abuse of right to European Copyright Misuse: a New Doctrine for EU Copyright Law. IIC 4:405-435

van Deursen S, Snijders T (2018) The Court of Justice at the crossroads: clarifying the role for fundamental rights in the EU Copyright Framework. IIC 49:1080-1098

Voorhoof D, Høedt-Rasmussen I (2013) Copyright vs. freedom of expression: the case Ashby Donald and others v. France. Kluwer Copyright Blog. http://copyrightblog.kluweriplaw.com/wp-content/ uploads/sites/49/2013/01/Dirk-Voorhoof-and-Inger-Hoedt-Rasmussen-Copyright-vs-Freedom-ofExpression-ECHR-Ashby-Donald.pdf. Accessed 30 Aug 2019

Voorhoof D, Høedt-Rasmussen I (2013) ECHR: Copyright vs. Freedom of Expression II (The Pirate Bay). Kluwer Copyright Blog. http://copyrightblog.kluweriplaw.com/2013/03/20/echr-copyright-vsfreedom-of-expression-ii-the-pirate-bay/. Accessed 13 Sept 2019

Publisher's Note Springer Nature remains neutral with regard to jurisdictional claims in published maps and institutional affiliations. 